\title{
Ülkü Mecmuasına Göre Erken Cumhuriyet Dönemi Nüfus Politikası (1923-1938)
}

\author{
Yrd. Doç. Dr. İbrahim ERDAL*
}

\begin{abstract}
$\ddot{O z e t}$
Türkiye Cumhuriyetinin kuruluş felsefesine uygun olarak işleyen kurumsal yapıların yanında rejimin ideolojisini yansitan süreli yayınlar da bulunmaktadır. Bunlardan birisi de Ülkü mecmuasıdır. Bu mecmuanın erken cumhuriyet döneminde devletin ideolojisinin halka yansittlması ve benimsetilmesinde önemli işlevi olmuştur. Dergi aynı zamanda dönemin sorunları üzerine de yazılar yayınlamıştır. $\mathrm{Bu}$ makalede rejimin sorunlarından birisi olan nüfus artışı üzerine Ülkü mecmuasında yayınlanmış olan yazılar derlenerek dönemin nüfus politikasına bakış incelenmiştir.
\end{abstract}

Anahtar Kelimeler: Ülkü mecmuası, Nüfus politikası, Cumhuriyet Dönemi, Doğum Oranı, Rejim

\section{Early Republican Era (1923-1938) Population Policy According to Ülkü Periodical}

\begin{abstract}
Beside the institutions functioning due to the founding philosophy of the Turkish Republic, there were also periodicals that reflects the ideology of the regime. One of them is the "Ülkü Mecmua". This periodical has a great importance

* Bozok Üniversitesi Fen Edebiyat Fakültesi Tarih Bölümü, YOZGAT, (ibrahim.erdal@bozok.edu.tr)
\end{abstract}


in the Early Republican Period to reflect the State Ideology to the public. The periodical at the same time published about the contemporary problems of its time. In this article it is discussed one of the important issues of the Regime - the population growth - according to the articles published in Ülkü Periodical and the regime's approach to the population policy.

Key Words: Ülkü Periodical, Population Policy, Early Republican Era, Birthrate, Regime

\section{Ülkü Mecmuası Hakkında}

Ankara Halkevinin yayını olan ve tek parti döneminde Cumhuriyet Halk Partisi'nin prensipleri doğrultusunda yayın yapan Ülkü dergisinde cumhuriyetin resmi ideolojisi ekseninde parti mensuplar1, devlet memurları ve entelektüeller yazılar yazmış, dergi halkevlerinin kapatılmasına kadar düzenli olarak yayınlanmış ve geniş bir sahaya dağıtılabilmiştir. ${ }^{1}$ Bizzat Atatürk'ün Uygurca “ülgü” kelimesinden alarak adını verdiği ${ }^{2}$ Ülkü dergisi, 1933-1950 yılları arasında üç farklı seride yayın yapmıştır. İlk seri 19331941 yıllarında 102 aylık sayıdan oluşmuştur. Bu seride halk sağlığından nüfus işlerine, sanattan köycülüğe kadar farklı alanlarda yazılar yayınlanmıştır. Fuad Köprülü 43. sayıdan itibaren editörlüğünü yapmıştır. $\mathrm{Bu}$ ilk seride Nusret Fuat Köymen, Fevziye Abdullah, Hasan Ali Yücel, Yaşar Nabi Nayır ve Pertev Naili Boratav yazılar yayınlamıştır. Derginin ikinci serisinde Ahmet Hamdi Tanpınar, Ahmet Kudsi Tecer, Suat Kemal Yetkin ve Bedri Rahmi Eyüboğlu'nun yazıları yayınlanmıştır. ${ }^{3}$ Yazarlarının kalitesi ve rejimin yayını olması gibi etkenlerle dergi ilk y1l 16.000 bask1 sayısına ulaşmıştır.

Ülkü dergisi kuruluş ve yayınlanma felsefesini daha ilk sayıda ortaya koymuş "Ülkü Niçin Çıkıyor" başlıklı yazısında:

"Ülkü karanlık devirleri arkada birakarak șerefli ve aydınlık bir istikbale giden yeni neslin heyecanını beslemek, cemiyetin kanındaki inkılâp unsurlarını ısıtmak(...)Ülkü, bu büyük yola katılanlar arasında kafa birliği

\footnotetext{
${ }^{1}$ Murat Tazegül Modernleşme Sürecinde Türkiye, Babil Yayınları, İstanbul, 2005, s.210; Hakkı Uyar, Resmi İdeoloji ya da Alternatif Resmi İdeoloji Oluşturmaya Yönelik İki Dergi: Ülkü ve Kadro Mecmualarının Karşılaştırmalı İçerik Analizi, Toplum ve Bilim Dergisi, 74/Güz 1997, s.182.

${ }^{2}$ Mehmet Ölmez, Ülkü Ve Dil Yazıları, Kebikeç, Yı1:2, Sayı:3, 1996, s.143.

3 Sarper Dost, Fotoğraf ve İdeoloji: Ülkü Dergisi Örneği 1941-1950, Hacettepe Üniversitesi Sosyal Bilimler Enstitüsü Yayımlanmamış Yüksek Lisans Tezi, Ankara, 2007, s.80.
} 
ve gönül birliği ve hareket birliği yapmak için (...) Ülkü, milli dile, milli sanatlara ve kültüre hizmet için...Ülkü bütün bu gayelere hizmet yolunda çalışan Halkevlerinin ruhundaki harareti yazı vasitalarıyla yaymak için çıklyor." ifadeleriyle rejimin ve ideolojinin resmi yayın organı olduğunu açıkça belirtmiştir. ${ }^{4}$

Yazarların ve yazıların kalitesiyle Ülkü dergisinin dönemin en yaygın dergisi olduğu ve resmi ideolojinin çözüm önerilerinin yayınlandığı muteber bir dergi olduğu yine derginin "Bir Yaşını Bitirirken" başlıklı makalesinden de anlaş1lmaktadır. Burada "Ülkü; yeni okuma ögrenenlerin değil, kültür işlerinde halka rehberlik edeceklerin mecmuasıdır. Bu itibarla umumiyetle anlaşıldĭ̆ Halkevlerinin, yani Halkevlerinde toplanan halk rehberlerinin mecmuası olmağl şiar edinmiştir." sözleriyle dergi eğitimli kitleye hitap ederek onlar üzerinden cumhuriyet ideolojisinin ve Cumhuriyet Halk Partisi'nin prensiplerinin halka benimsetilmesi planlanmıştır. ${ }^{5}$

\section{Avrupa ve Türkiye'de Nüfus Meselesine Bakış}

20. yüzyıl Avrupa'sında ulus devlet modeli çerçevesinde homojen bir toplum yaratmak veya oluşturulmuş bu toplumsal yapıyı sağlıklı bir şekilde çoğaltabilmek bağlamında bir dizi uygulamalar yapılmıştır. Özellikle Balkan ülkelerinde mübadele ve toprak kanunu gibi resmi yollarla sınırlar içerisinde homojen bir toplum yap1s1 kurmak en önemli uygulamalardan birisi olmuştur. ${ }^{6}$ I. Dünya Savaşından sonra da ulus devletlerin bu politikaları devam ettirdikleri görülmüştür. Savaş sonrası üreten sınıfın arttırılması uğraşına giren Avrupa'da bu amaçla çeşitli kongreler düzenlenmiş, Nüfus politikasının nasıl olması ve yürütülmesi gerektiği konusunda fikirler ileri sürülmüştür. Özellikle İtalya'da, Mussolini Hükümeti nüfus politikası uygulamalarında her alanda projeler yürütmüş bu sebeple Avrupa'da Türkiye'yi etkileyen en önemli ülke İtalya olmuştur.

Mussolini; İtalya'da uygulamaya koyduğu nüfus politikasını "azami doğum ve asgari ölüm” dengesi üzerine inşa etmiştir. Bu sebeple Mussolini hükümeti ana çocuk sağlığına önem vermiş, göçü önlemek için önlemler almış, doğum ve evliliği desteklemiştir. Mussolini yasal düzenlemelere

\footnotetext{
4 "Ülkü Niçin Çıkıyor", Ülkü Mecmuası, 1933, Cilt:1, Sayı:1, s:1-2; Çilem Tercüman, Ülkü Mecmuası, Türkiye Araştırmaları Literatür Dergisi, Cilt: 4, Sayı: 7, 2006, s. 563.

5 "Bir Yaşını Bitirirken", Ülkü Mecmuası, 1934, Cilt:1, Sayı:12; s.1-2; Firdevs Gümüşoğlu; Ülkü Dergisi ve Kemalist Toplum, Toplumsal Dönüşüm Yayınları, İstanbul 2005, s. 147-158.

${ }^{6}$ Bknz. İbrahim ERDAL, Uluslaşma Sürecinde Türkiye ve Yunanistan 1923-1925, IQ Kültür Sanat Yayınevi, İstanbul, 2006, s.21, 29-30.
} 
giderek 25-55 yaş arasındaki bekârları vergilendirmiş ve bu vergi gelirlerini ana çocuk sağlı̆̆ 1 ile ilgili harcamalara aktarmıştır. Ayrıca 7 ve daha fazla çocuk sahibi olan ailelere vergi muafiyeti getirirken memurlardan çocuk sahibi olanlara da aile zammı vermiştir.

Cumhuriyetin ilk yıllarında genç devletin nüfus oranını yükseltebilmek amaciyla Avrupa'da uygulanmış ve uygulanmakta olan politikalar aynen izlenmeye çalışılmıştır. Avrupa'da özellikle İtalya'da Mussolini Hükümetinin bu amaçla çeşitli tedbirler aldığı ve yayınlar yaptığı bu yayınlarında Türkiye'de tercüme edilerek değerlendirildiği görülmüştür: ${ }^{8}$ Aynı dönemde meclis konuşmalarının yanında basın ve bilim adamları da konu hakkında yazılar yazmaya Avrupa'da bu konuda yayınlanmış olan eserlerin çevirisinin yapılmasına ve çözüm önerilerinin Türkiye'de uygulanmasına çalışılmıştır. ${ }^{9} 1932$ yılında Fernand Boverat'ın Avrupalı sosyolog ve iktisatçıların nüfus artışı üzerine tartışmalarına yer verdiği "Avrupa Nüfusunun İstikbali 1931 Roma beynelmilel Nüfus Kongresi Mesaisinden" ve François Marshal'ın yasal düzenlemelerin nüfus artışındaki önemli etkisi üzerinde duran "Kanunların Nüfus İnkişafına Tesirleri" adlı eserleri çevrilerek yayınlanmıştır. ${ }^{10} 1934$ yılında Charles Balas'ın nüfus artışında bir denge kurulması gerektiğini savunan "Nüfus işlerinde Nereye Gidiliyor?" başlıklı eseri İstatistik Umum Müdürlüğünce çevrilmiştir. Bu eserde de yazar, refah seviyesinin yüksekliği doğum oranında düşüşe, hızlı nüfus artışının da sosyal ve ekonomik dengede bozulmaya sebep olacağına dikkat çekmiştir. ${ }^{11}$

$\mathrm{Bu}$ çeviri yayınların yanında Türkiye'de de birçok akademisyen nüfusun artırılması hususunda yayın yapmıştır. M. Şekip Tunç, 1932 yılında yayınladığı bir makalede Avrupa'daki maddi doyumun nüfus artışının önündeki en önemli engel olduğuna değinerek Türkiye'de geçim şartlarının

\footnotetext{
${ }^{7}$ Gaetano Zıngali; Nüfusun Kemiyet ve Keyfiyeti inkişafı için Italya'da Alınan Tedbirler, Çev: Yusuf Adil, Ankara, 1932, s.3-12.

${ }^{8}$ Adnan Güriz; Türkiye'de Nüfus Politikası ve Hukuk Düzeni, Türkiye Kalkınma Vakfı Yayını: 2, Ankara, 1975, s.54. Türkiye'de de 1926 yılında memurin kanununda yapılan düzenlemelerle çocuk sahibi olan memurların çocuklarının eğitimleri konusunda devlet desteği verildiği, çok çocuklu memurlara da çocuk sayısı kadar desteklendiği görülmektedir. a.g.e., s. 141-147. s. 6,8 .

${ }^{9}$ L. Rabinowicz; Nüfus Meselesi, Çev.: Aleaddin Cemil, Ankara, 1930, İktisat Matbaası,

${ }^{10}$ Fernand Boverat; Avrupa Nüfusunun İstikbali, 1931 Roma Beynelmilel Nüfus Kongresi Mesaisinden, Çev: M. Celal, Ankara, 1932. s. 4-6; François Marshall; Kanunların Nüfus İnkişafina Tesirleri; 1931 Roma Beynelmilel Nüfus Kongresi Mesaisinden, Çev: M. Celal, Ankara, 1932, s.3.

${ }^{11}$ Charles Balas; Nüfus Işslerinde Nereye Gidiliyor? Çev: Aykut Selim Sabit, İstanbul, 1934, s.1.
} 
farklılığından dolayı bu durumun tam tersinin olduğunu Türk toplum yapısında çok çocuk yapmanın daha tercih edilebilir olduğunu belirtmiştir. ${ }^{12}$ İsmail Hüsrev Tökin de aynı yıl yazdığı bir makalede Asya'daki nüfus hareketlerini incelemiş, Türkiye'de nüfus sorununa ve çocuk ölümlerine değinerek, Türkiye'de teknik ve bilimde yükselerek üretimde artış sağlanamaması, modern kültürün, yaşam tarzının ve tekniğin ülkenin en ücra köşelerine nüfuz edememesi durumunda sağlıklı nüfus artışının sağlanamayacağını savunmuştur. ${ }^{13}$.

Şevket Süreyya Aydemir ise nüfus konusunda ilk defa yayın ve istatistik yayınlayan Himaye-i Etfal Cemiyetinin verdiği bilgilere itiraz etmiştir. Aydemir, Anadolu'da kadınların doğurganlığından şüphe edilmeyeceğini fakat sağlıklı bir nesil yetiştirmek için anneye sağlık, beslenme gibi temel hizmetlerin sağlanması gerektiğini belirterek "Anaya çocuğunu ve çocuğa sihhatini temin etmek işi, dünyanın her yerinde artık bir devlet meselesi olmuştur. Ananın çocuğunun sihhatini, artık her yerde devletten beklemesi hakkıdır." 14 görüşünü savunmuştur. 1927 nüfus sayımında ortaya çıkan orandan daha fazlasının Anadolu coğrafyasında yaşayabileceğini iddia eden Aydemir, yazısında hükümetin hedefinin çok nüfuslu ileri teknikli, tok, şen ve kalabalık bir Türk milleti olması gerektiğini vurgulamıştır.

Avrupa'da nüfus yoğunluğuna gösterilen önem cumhuriyetin ilk yıllarında Türkiye'de de vurgulanmıştır. Gazi Mustafa Kemal (Atatürk) 1 Mart 1922 tarihinde yaptığı TBMM'nin üçüncü toplanma yılını açış konuşmasında; sağlık ve sosyal yardım politikalarına önem verildiğini, asıl amacın ölüm oranını azaltmak ve doğum oranını arttırmak olduğu bu sayede sağlıklı ve üretken bir nüfusun oluşturulması olduğunu ifade etmiştir. Gazi Mustafa Kemal (Atatürk) yine 1 Mart 1923 günü Türkiye Büyük Millet Meclis'inin Dördüncü Toplanma yılını açış konuşmasında ise nüfus sorunun önemli bir yere sahip olduğuna ve özellikle nüfus sayımı konusunun önemine değinmiş, memleketin nüfusun tespiti ${ }^{15}$ ve çoğaltılması için gerekli yasal düzenlemelerin kısa sürede hazırlanması gerektiğine vurgu yapmıştır. ${ }^{16}$

${ }^{12}$ M. Şekip Tunç; "Nüfus Sayımı Kalkınma Çağı”, Nüfus Meselesi ve Nüfus Sayımı Hakkında Fikirler, İstatistik Umum Müdürlüğü Yayını, Ankara, 1932, s.137-138.

13 İsmail Hüsrev Tökin; “Asya'da Nüfus Hareketleri”, Kadro Mecmuası, Sayı: 4, Nisan 1932. 1932

${ }^{4}$ Şevket Süreyya Aydemir; "Çok Nüfuslu Anadolu”, Kadro Mecmuası, Sayı: 5, Mayıs

${ }^{15}$ Osmanlı Devleti'nin en son yaptığı 1914 nüfus sayımına göre toplam nüfus 14.255.913 kişidir. 1927 yılında yapılan nüfus sayımında ise toplam nüfus 13.648.270 kişidir. 1927 sayımına göre 20-55 yaş aralığında her 1000 kadına 824 erkeğin düşmesi yaklaşık 13 yıl sonra dahi 1914 nüfusuna ancak yaklaşıldığı ve yaşanan süreçteki savaşların, salgın 
Atatürk Türkiye Büyük Millet Meclisi İkinci Dönem Birinci Toplanma yılını açarken 1 Mart 1924 günü yaptı̆̆ı konuşmasında; “... Nüfusumuzun muhafaza ve tezyidi gayesini ehemmiyetle nazarl dikkate vaz ederim. Sihhati umumiye için esasl olarak derpiş edilen tedabir aleddevam ikmal ve tevsi olunmalıdır. Feyyaz ve velut olan Türk Milleti mütemadi ve fenni takayyüdat sihhiyeye mazhar olunca Türk vatanın süratle dolduracak ve şenlendirecek kuvvette olduğuna kimsenin şüphesi yoktur" sözlerinde yaptı̆̆ 1 vurgu ile nüfusun artırılması tezinin devlet politikası olarak açıkça benimsendiği anlaşılmaktadır. Atatürk'ün aynı yıl Meclisin ikinci toplanma yılı açılış konuşmasında da salgın hastalıklarla mücadele edilmesini, ölümleri azaltmanın ve nüfusu çoğaltmanın yararlı ve hatta zorunlu bir metodu olarak nitelendirmektedir. Bu konuşma, özellikle sıtmaya karşı savaş açılmasına öncelik tanındığını ortaya koymuştur.

1 Kasım 1925 ve 1926 tarihlerinde TBMM açılış konuşmalarında konuya hassasiyetle değinen Atatürk halk sağlığı konusunun sitma ve salgın hastalıklarla mücadele ${ }^{17}$ kapsamında sağlıklı, genç ve üretken bir nesil için önemli olduğu vurgusunu yapmıştır. 1 Kasım 1929 günü Meclisin Üçüncü Dönem Üçüncü Toplanma yılı açış konuşmasında: "Geçen sene memleketin sihhati mühim bir arıadan müteessir olmaksızın geçmiştir. Her nevi sıhhi mücadeleyi, mümkün olan derecede seri ve geniş bir surette takip etmek başlıca hedeflerden olmaya layıktır". ${ }^{18}$ diyerek 1924-1929 yılları arasında yapılan başarılı mücadeleye işaret etmiştir. Salgın hastalıklar sonucunda oluşan hasta ve sakat nüfus oranının ise başarılı bir uygulama sonucunda 1935 yılında yapılan nüfus sayımına göre azalma eğiliminde olduğu görülmüşsür. ${ }^{19}$

hastalıkların ve göçlerin etkisinin büyüklüğü kolaylıkla anlaşılmaktadır. Bknz, 1927 Türkiye Nüfusu, Merkez İstatistik Müdüriyeti Umumiyesi, Ankara, 1928; Cerm BEHAR, Osmanl Imparatorluğu ve Türkiye'nin Nüfusu 1500-1927, İletişim Yayınevi, İstanbul, 1996.

${ }^{16}$ Atatürk Söylev ve Demeçleri I, İstanbul, 1945, s. 217, 277-278.

${ }_{17}$ Sağlık Hizmetlerinde 50 Yll, Sağlık ve Sosyal Yardım Bakanlığı Yayını, No:422, Ankara, 1973, 1920'li yıllarda Sitma, Verem, Frengi, Trahoma, Tifo ve Difteri gibi salgin hastalıklar yaygın olduğu çocuklarda görülen ölüm oranlarından anlaşılmaktadır. 1933 yılında yayınlanan verilere göre sadece 33 ilde ölüm oranı hızı \%20 dir. Aynı şekilde cumhuriyetin kuruluş yıllarında trahoma hastası 3 milyon kişidir. 1917-1925 yılları arasına ait verilere göre ise Denizli ve Antalya bölgesinde sitmalı oranı \%86, Trakya'da ise \%30 civarındadır. Kurtuluş Savaşı'nda da Türk ordusunun \%40'ında sitma tespit edilmiştir.

${ }_{18}$ Atatürk Söylev ve Demeçleri I, s. 316, 321-322, 347.

191935 Yerel Nüfus Sayımı, Türkiye Cumhuriyeti Başbakanlık İstatistik Genel Direktörlüğü, İstanbul, 1939. 1935 y1lı nüfus sayımına göre toplam nüfus 16.158 .018 kişidir. 0-9 yaş arasındaki çocuklar arasındaki sakatlık oranı \%2 olarak verilmiştir. 


\section{Ülkü Mecmuasında Nüfus Politikası Üzerine Tartışmalar}

Ülkü mecmuasında nüfus sorunu ile ilgili yapılan tartışmaların ana konusu; devletin sahip olduğu yüzölçümüne göre az olan nüfusun hangi yollarla çoğaltılacağ 1 olmuştur. Tartışmalar iki çözüm önerisi üzerinde yoğunlaşmış bunlardan birincisi yurtdışı göçler diğeri de iç göçler ile köylerin ve köylülerin durumu üzerine odaklanmıştır. Her iki görüşü de savunanlar arasında çok az görüş farkı bulunmaktadır.

Ülkü mecmuasında nüfus ile ilgili ilk olarak Dr. Zeki Nasır nüfusun çoğalması için gerekli teknik şartlar üzerine bir dizi yazı yayınlamıştır. "Nüfus İşinin Tetkiki" başlıklı yazısında Anadolu'da özellikle sıtma ve frengi ile mücadelenin önemine değinen Nasır, Anadolu'da bu tür mücadelenin yapıldığı bölgelerde nüfusun artarak çoğaldığının gözlemlendiğine dikkat çekerek, sağlıksız ailelerden sağlıksız neslin oluşacağına vurgu yapmıştır. ${ }^{20}$ "Köylerimizin Sağlık işleri” başlıklı yazısında da nüfus artışının en önemli kaynağı olan köylerde çocuk ölümlerinin azaltılması için çalışmaların yapılması gerektiğine, burada yaşayan insanların bilgilendirilerek daha sağlıklı bir doğum oranının yakalanabileceğini vurgulayan ${ }^{21}$ yazar özellikle ailelerin sağlık eğitiminden geçirilmesine önem vermiştir. Hükümetin çeşitli vilayetlerde "Doğum ve Çocuk Bakım Evleri” ve Ankara'da "Merkez Hıfzısıhha Müessesesi"ni kurması, bu merkez ve evlerin devletin sağlık koruma işlerini yöneten ve ulusun sağlık standardını yükselten bir merkez olacağ 1 ifade edilmiştir. ${ }^{22}$

Ülkü'de yazanlardan Nusret Kemal nüfus konusuna ideolojik bir yaklaşım getirmiş, 1934 yılında "İnkılâp İdeolojisinde Halkçılık" başlıklı makalesinde halkçılık ilkesini "...bu tabakayı manen ve maddeten yükselterek ve adetçe arttırarak memlekette tam manastyla hâkim kllmak..." şeklinde açıklayarak genç Cumhuriyette rejimin tamamen oturması için gerekli olan nüfusun artışına değinmiştir. ${ }^{23}$ Nüfus konusunun ideolojik değerlendirmeler kapsamına alınmasıyla Fahrettin Kerim (Gökay) da "Milli Nüfus siyasetinde (Eugenique) Meselesinin Mahiyeti" başlıklı makalesinde: ruhen ve bedenen zinde, yani keyfiyet itibariyle de yüksek klymette bir nüfus

\footnotetext{
${ }^{20}$ Zeki Nasır, "Nüfus İşinin Tetkiki”, Ülkü Mecmuası, Haziran Cilt: I, Sayı 5, Haziran 1933, s. $414-416$.

${ }^{21}$ Zeki Nasır, "Köylerimizin Sağlık İşleri”, Ülkü Mecmuası, Cilt: 2, Sayı 7, Ağustos 1933, s. 45 .

${ }^{22}$ Zeki Nasır, "Sağlığı Koruma Terbiyesi”, Ülkü Mecmuası, Cilt: 2, Say1 9, Birinci Teşrin 1933, s. 297; “Cumhuriyetin Sağlık Bakım ve Yardım işleri”, Ülkü Mecmuası, Cilt: 2, Sayı: 9 , Birinci Teşrin 1933 s. 253 - 257.

${ }^{23}$ Nusret Kemal, “İnkılâp İdeolojisinde Halkçılık”, Ülkü Mecmuası, Cilt: 3, Sayı: 13 Mart 1934, s. 41.
} 
kesafeti yaratmaya çalıșmak inkılâbımızın en sarih umdelerinden birini teşkil eder" sözleriyle milli nüfus politikasının, nüfusu çoğaltarak ölümü azaltmak ve zinde nüfus yetiştirmek amacını hedef alan hareket olmasını belirtmiştir." 24

Cumhurbaşkanı Atatürk de 1 Kasım 1934 günü, Türkiye Büyük Millet Meclisinin Dördüncü Dönem Dördüncü Toplanma yılını açarken yaptığ 1 konuşmada, sağlık çalışmalarının önemine dikkat çektiği gibi, bu alandaki uygulamanın özellikle genç nesillerin sağlığı yönünden olumlu biçimde geliştiği fikrini benimsediğini ortaya koymuştur. ${ }^{25}$

Dönemin Başbakanı İsmet İnönü ise 1935 y1lı nüfus sayımı sonuçları hakkında Ülkü Dergisine verdiği demecinde, 1927 yılında yapılmış olan nüfus sayımıyla kıyaslayarak, 2.509.748 kişilik nüfus artış oranını, ekonomik sıkıntılara rağmen cumhuriyetin nüfus politikasının bir başarısı olarak kabul etmiştir. ${ }^{26} 1935$ ikinci Nüfus Sayımının sonuçları Falih Rıfkı (Atay) tarafından da başarı olarak kabul edilmiş, “...Yeni asır tekniği ile cihazlanmış Anadolu'da 16 milyonluk kuvvetli ve cesur bir halkın döğ̈̈ştürülebileceği ordular, dişarıdan gelecek her türlü tehlikeyi bir tarafa atmış demektir..." sözleriyle Osmanlıdan bu yana göçlere, isyanlara ve hastalıklara rağmen cumhuriyetin nüfus politikasının hedeflerine geniş ölçüde ulaştığını ifade etmiştir. ${ }^{27}$

Zeki N. Barker'in 1935 yılında yazdığı "Yavrularımızın Değerini Bilelim" başlıklı yazısında ise çocuklar üzerinde durmuş, Cumhuriyet döneminde geçen barış yıllarının nüfusun çoğalmasında etkili olduğunu, cumhuriyetin nüfus politikasını uygulamaya çalıştığını ancak tam başarı için ekonomik şartların genişlemesinin en önemli şart olduğunu ifade etmiştir. Nüfus artışı için uygulanan politikaların önemli olduğunu ancak durumun sadece doğum olmadığını doğan çocukların yaşatılmasının da ayrı bir önem arz ettiğini belirtmiştir. ${ }^{28}$

Necip Ali Küçüka'nın “Çocuk Düşürme” başlıklı yazısı da çocuk düşürme konusunda İslam ve Osmanlı ceza hukuku ile Avrupa kanunlarındaki hukuki düzenlemeleri değerlendirerek zorunlu olmayan

\footnotetext{
${ }^{24}$ Fahrettin Kerim Gökay, "Milli Nüfus Siyasetinde (Eug6nique) Meselesinin Mahiyeti”, Ülkü Mecmuası, Cilt: 3, Sayı: 15, Mayıs 1934, s. 206.

${ }^{25}$ Atatürk'ün Söylev ve Demeçleri, I, İstanbul, 1945, s. 363.

26 "Nüfus Sayımı", Ülkü Mecmuası, Cilt: 6, Sayı: 23, İkinci Teşrin 1935, s. 209.

${ }^{27}$ Falih Rıfkı Atay; "Nüfus Sayımı", Ülkü Mecmuası, cilt 6, savı 33, İkinci Teşrin 1933, s.211.

${ }^{28}$ Zeki N. Barker; "Yavrularımızın Değerini Bilelim”, Ülkü Mecmuası, Cilt: 5, Sayı: 27, May1s 1935, s. 206
} 
hallerde çocuk düşürmeyi nüfus politikası açısından bir ihanet olarak algilamıştır. $^{29}$ İstatistik Umum Müdürlüğünce 1936 yılında yayınlanan "Nüfus Meselesi ve Nüfus sayımı Hakkında Fikirler" isimli eser bu konuda yazarların, politikacıların, bilim adamlarının görüşlerini yansıtmaktadır. Sözünü ettiğimiz eserde görüşleri yer alan yazarların hemen hemen tamamının nüfusu arttırma olarak belirtilen resmi devlet politikasını benimsedikleri ve destekledikleri anlaşılmaktadır.

Türkiye Cumhuriyeti'nin çok nüfusa sahip olmasının ve bunun hızlı bir şekilde başarılmasının göç yoluyla olacağını savunanlar arasında Şevket Aziz (Kansu) da bulunmaktadır. Kansu "Türk Topraklarının Adamı" başlıklı yazısında nüfusu artırmak için iç göçlerin teşvik edilmesi gerektiğine de işaret etmiş, "yaşam şartları daha iyi olan bölgelerimize iç göç yaptırarak buralardaki doğurganlık oranının daha da arttırılabileceğini " Sağlam bioantropolojik metotlarla üreyen nüfus kütlesinin fazlası memleketin nüfusu az mıntıkalarına bir plan içinde dağıtılmalıdır" "30 sözleriyle savunmuştur.

Göç yoluyla çözüm konusunda Kansu ile aynı fikirde olan Yaşar Nabi, bu göçün içerden değil dişarıdan olmasına vurgu yapmıştır. Yaşar Nabi (Nayır)'ın "Nüfus Meselesi Karşısında Türkiye" başlıklı yazısında toplumun eğitiminin sağlıkta ilerlemek ve ölüm oranlarının azaltılmasından daha önemli olduğunu çünkü ölüm oranını düşüren ilerlemiş ülkelerde doğum oranında azalma olduğuna işaret etmiştir. Yazar yazısında toplumun eğitilmesinin yanında Bulgaristan, Romanya ve Yugoslavya'da bulunan Türklerin Anadolu'ya iskânlarıyla da nüfusun daha sağliklı ve hızla arttırılabileceği ifade edilmiştir. Nayır makalesinde, "Balkanlardan memleketimize bir buçuk milyona yakın vatandaş getirmek mümkündür. Bu insanlar hele süratle çoğalan bir ırka mensup olunca, nüfusa ihtiyacı olan bir memleket için büyük bir nimettir" ${ }^{31}$ sözleriyle bu politikanın ancak milli bir politika ile oluşabileceğini içerde uygulanan politika ile yılda yirmi bin kişi kazanmaktansa kötü şartlarda yaşamakta olan vatandaşların göçüyle daha hızlı artışın sağlanacağını savunmuştur.

\footnotetext{
${ }^{29}$ Necib Ali Küçüka; “Çocuk Düşürme”, Ülkü Mecmuası, Cilt: 7, Sav1: 37, Mart 1936, s. $23-26$.

${ }^{30}$ Şevket Aziz Kansu; "Türk Topraklarının Adamı”, Ülkü Mecmuası, Cilt: 4, Sayı: 24, Birinci Teşrin 1934, s. 81.

${ }^{31}$ Yaşar Nabi Nayır; "Nüfus Meselesi Karşısında Türkiye”, Ülkü Mecmuası, Cilt: 14, Sayı: 79, Eylül 1939, s. 33-36.
} 


\section{Sonuç}

Döneminin ideolojik bakış açısını açıkça ortaya koymuş olan Ülkü Mecmuasındaki nüfus tartışmalarına genel olarak baktığımızda iki ana hususta tartışmaların yoğunlaştığı anlaşılmaktadır. Bunlardan birincisi, nüfusun hızla artışını sağlayabilmek amacıyla Türkiye sınırları dışında yaşamakta olan Türklerin Anadolu'ya getirilerek iskânlarının yapılması ve Türkiye içindeki bölgelerden diğer yerlere doğru nüfus yoğunluğunun dengelenmesi fikri olmuştur. Ancak bu fikrin etrafinda toplanan yazılarda da yurtdışından getirilecek olan bu Türk nüfusun nereye yerleştirileceği ve bu nüfusun uyumlarının sağlanarak nasıl hızla üretici hale getirilebilecekleri konusunda görüş ayrılıkları yaşanmıştır. Bu konuda Atatürk TBMM'nin dönem açılış konuşmalarında da açıklamalarda bulunmuş, göçmenlerin bir an önce üretici hale getirilmesinin önemine vurgu yapmıştır.

Ülkü mecmuasında nüfus ile ilgili ikinci tartışılan husus ise refah seviyesinin arttırılmasının nüfus artışına olan etkisi üzerine olmuştur. Burada da Avrupa'yı örnek veren yazarlardan bazıları refah ve eğitim seviyesinin artışının ailelerin çocuk yapma isteklerini azalttığı bu durumunda nüfus artış hızına ters etki yapacağ 1 görüşünü dile getirmişlerdir. Bu görüşe karş1 gelenler ise eğitilmiş bir toplumun özellikle sağlık yönünden sorunu olmayan bir toplumun doğurganlığının azalmayacağı aksine ölüm oranlarının azalmasıyla nüfus artışında bir ivme kazanılabileceği iddia edilmiştir. $\mathrm{Bu}$ konuda Anadolu kadınının savaş şartlarında dahi doğurganlığını kaybetmediğini savunanlar sağlık şartlarının iyileştirilmesi durumunda nüfus artışında azalma görülmeyeceğini savunmuşlardır. Dönemin kayıtlarını incelediğimizde bir bütün olarak salgın hastalıkla mücadele için yapılan uygulamalar ve sonuçları ile ilgili kayıtların ilden ile değiștiğini birçok ilden bilgi akıșının olmadığı görülmüștür. Ancak milli mücadele döneminin şartlarının belirginliği 1927 nüfus sayımında çıkan sonuç salgın hastalıkların ne derece etkili olduğunu açıkça göstermiştir.

Bu sebeple Ülkü mecmuasında yaşanan bu tartışmalara bakıldığında 1930'lu yıllarda özellikle 1927 nüfus sayımından sonra cumhuriyet hükümetlerinin ve resmi ideolojinin Anadolu'da verimli, sağlıklı ve üreten bir nüfus yaratmayı ilke edindiği bu amaçla bürokrasinin kurum ve kuruluşlarını harekete geçirdiği görülmektedir. Entelektüellerin ise özellikle Avrupa'da bu konuda yayınlanmış olan makale ve kitapları tercüme ederek konuyu tartıştıkları uygulanmak üzere hükümetlere çözüm önerileri sunduğunu anlaşılmaktadır. Konuya verilen önem dönemin başbakanı olan İsmet İnönü'nün 1935 nüfus sayımında yaklaşı 2.509.748 kişilik nüfus artışını bir başarı olarak ifade etmiş olmasından anlaşılmaktadır. 


\section{KAYNAKÇA}

\section{Resmi Yayınlar}

1927 Türkiye Nüfusu, Merkez İstatistik Müdüriyeti Umumiyesi, Ankara, 1928.

1935 Genel Nüfus Sayımı, Türkiye Cumhuriyeti Başbakanlık İstatistik Genel Direktörlüğü, İstanbul, 1939.

Sağllk Hizmetlerinde 50 Yll, Sağlık ve Sosyal Yardım Bakanlığı Yayını No:422, Ankara, 1973.

\section{Kitaplar ve Makaleler}

Atatürk'ün Söylev ve Demeçleri, I, İstanbul, 1945.

Aydemir, Şevket Süreyya; "Çok Nüfuslu Anadolu”, Kadro Mecmuası, Sayı: 5, 1932.

Balas, Charles, Nüfus işlerinde Nereye Gidiliyor? Çev: AYKUT Selim Sabit, İstanbul, 1934.

BEHAR, Cerm, Osmanlı İmparatorluğu ve Türkiye'nin Nüfusu 1500-1927, İletişim Yayınevi İstanbul, 1996.

Boverat, Fernand; Avrupa Nüfusunun istikbali, 1931 Roma Beynelmilel Nüfus Kongresi Mesaisinden, Çev: M. Celal, Ankara, 1932.

Dost, Sarper; Fotoğraf ve İdeoloji: Ülkü Dergisi Örneği 1941-1950, Hacettepe Üniversitesi Sosyal Bilimler Enstitüsü yayımlanmamış Yüksek Lisans Tezi, Ankara, 2007.

ERDAL, İbrahim, Uluslaşma Sürecinde Türkiye ve Yunanistan 1923-1925, IQ Kültür Sanat Yayınevi, İstanbul, 2006.

Gümüşoğlu, Firdevs; Ülkü Dergisi ve Kemalist Toplum, Toplumsal Dönüşüm Yayınları, İstanbul, 2005.

Güriz, Adnan; Türkiye'de Nüfus Politikası ve Hukuk Düzeni, Türkiye Kalkınma Vakfi Yayını: 2, Ankara, 1975.

Marshall, François; Kanunların Nüfus Inkişafina Tesirleri; 1931 Roma Beynelmilel Nüfus Kongresi Mesaisinden, Çev: M. Celal, Ankara, 1932.

Ölmez, Mehmet; Ülkü Ve Dil Yazıları, Kebikeç, Yı1:2 Sayı:3, 1996.

Rabinowicz, L.; Nüfus Meselesi, Çev.: Aleaddin Cemil, İktisat Matbaası, Ankara, 1930.

Tazegül, Murat; Modernleşme Sürecinde Türkiye, Babil Yayınları, İstanbul, 2005.

Tercüman, Çilem; Ülkü Mecmuası, Türkiye Araştırmaları Literatür Dergisi, Cilt:4, Say1:7, 2006. 
Tökin, İsmail Hüsrev; “Asya'da Nüfus Hareketleri”, Kadro Mecmuası, Sayı: 4, Nisan, 1932.

Tunç, M. Șekip; "Nüfus Sayımı Kalkınma Çağıdır”, Nüfus Meselesi ve Nüfus Sayımı Hakkında Fikirler, İstatistik Umum Müdürlüğü Yayını, Ankara, 1932.

Uyar, Hakkı; Resmi İdeoloji ya da Alternatif resmi ideoloji oluşturmaya Yönelik İki Dergi: Ülkü ve Kadro Mecmualarının Karşılaştırmalı İçerik Analizi, Toplum ve Bilim Dergisi, 74/Güz 1997.

Zıngali, Gaetano; Nüfusun Kemiyet ve Keyfiyeti inkişafi için Italya'da Alınan Tedbirler, Çev: Yusuf Adil, Ankara, 1932.

\section{Ülkü Mecmuasından Makaleler}

“Ülkü Niçin Çıkıyor”, Ülkü Mecmuası, Cilt:1, Sayı:1, Ankara, 1933.

“Bir Yaşını Bitirirken”, Ülkü Mecmuası, Cilt:1, Sayı:12; Ankara, 1934.

"Nüfus Sayımı”, Ülkü Mecmuası, Cilt: 6, Sayı: 23, Ankara, 1935.

Atay, Falih Rıfkı; "Nüfus Sayımı”, Ülkü Mecmuası, Cilt: 6, Savı: 33, Ankara, 1933.

Barker, Zeki N; "Yavrularımızın Değerini Bilelim”, Ülkü Mecmuası, Cilt: 5, Sayı: 27, Mayıs, Ankara, 1935.

Gökay, Fahrettin Kerim; "Milli Nüfus Siyasetinde (Eug6nique) Meselesinin Mahiyeti”, Ülkü Mecmuası, Cilt: 3, Sayı: 15, Mayıs, Ankara, 1934.

Kansu, Şevket Aziz; “Türk Topraklarının Adamı”, Ülkü Mecmuası, Cilt: 4, Sayı: 24, Birinci Teşrin, Ankara, 1934.

Kemal, Nusret; "İnkılâp İdeolojisinde Halkçılık”, Ülkü Mecmuası, Cilt: 3, Sayı: 13, Mart, Ankara 1934.

Küçüka, Necib Ali; “Çocuk Düşürme”, Ülkü Mecmuası, Cilt: 7, Savı: 37, Mart, Ankara 1936.

Nasır, Zeki; "Cumhuriyetin Sağlık Bakım ve Yardım işleri”, Ülkü Mecmuası, Cilt: 2, Sayı: 9, Birinci Teşrin, Ankara 1933.

Nasır, Zeki; “Köylerimizin Sağlık İşleri”, Ülkü Mecmuası, Cilt: 2, Sayı: 7, Ağustos, Ankara 1933.

Nasır, Zeki; "Sağlığı Koruma Terbiyesi”, Ülkü Mecmuası, Cilt: 2 Sayı: 9, Birinci Teşrin, Ankara 1933.

Nasır, Zeki; "Nüfus İşinin Tetkiki”, Ülkü Mecmuası, Haziran Cilt: I, Sayı: 5. Haziran, Ankara 1933.

Nayır, Yaşar Nabi; "Nüfus Meselesi Karşısında Türkiye", Ülkü Mecmuası, Cilt: 14, Say1: 79, Eylül, Ankara 1939. 